\title{
Interpopulational differences in the female reproductive cycle of the southwestern Atlantic estuarine crab Chasmagnathus granulatus Dana, 1851 (Brachyura: Grapsoidea: Varunidae)
}

\author{
ROMINA B. ITUARTE ${ }^{1,2}$, CLAUDIA BAS ${ }^{1,2}$, TOMÁS A. LUPPI ${ }^{1,2}$ \\ and EDUARDO D. SPIVAK ${ }^{1,2}$ \\ ${ }^{1}$ Departamento de Biología, Facultad de Ciencias Exactas y Naturales, Universidad de Mar del Plata, Casilla de Correo \\ 1245, 7600 Mar del Plata, Argentina. E-mail: ituarte@mdp.edu.ar; roituarte@yahoo.com.ar \\ ${ }^{2}$ Consejo Nacional de Investigaciones Científicas y Técnicas, Argentina.
}

SUMMARY: The female reproductive biology of Chasmagnathus granulatus Dana, a semiterrestrial burrowing crab endemic to the southwestern Atlantic, was compared in two contrasting coastal habitats: San Antonio (SA, marine) and Mar Chiquita (MC, estuarial). Mature females were collected monthly for 1.5 years and the ovarian cycle was described using a qualitative scale. Gonadosomatic (GSI) and hepatosomatic (HSI) indexes were calculated. The highest GSI and HSI occurred early in the reproductive season in SA and during the non-reproductive season in MC. The beginning and duration of the reproductive season also differed between populations: it started later and was shorter in SA. In MC, secondary vitellogenesis continued when the reproductive season had finished, and the ovaries remained fully developed throughout the nonreproductive season (winter). Therefore, females of $\mathrm{MC}$ were ready to lay eggs as soon as spring environmental conditions appeared. However, SA females did not attain a fully developed ovary during winter. A limited food supply would restrict the available energy to complete secondary vitellogenesis at the end of the reproductive season in SA, after the last spawning. Thus, the vitellogenic cycle should be completed in the following spring, causing a delay in the beginning of the reproductive period. In addition, the higher temperature amplitude may cause the reproductive period in SA to end early.

Keywords: estuary, crab, Argentina, ovarian cycle, gonadosomatic index, hepatosomatic index.

RESUMEN: DIFERENCIAS INTERPOBLACIONALES EN EL CICLO REPRODUCTIVO FEMENINO DEL CANGREJO ESTUÁRICO ChASMAGNATHUS GRANULATUS DANA, 1851 (BRACHYURA: GRAPSOIDEA: VARUNIDAE) DEL ATLÁNTICO SUDOCCIDENTAL. - La biología reproductiva de las hembras de Chasmagnathus granulatus Dana, un cangrejo semiterrestre y excavador endémico del Atlántico Sudoccidental, fue comparada entre dos localidades costeras con regímenes ambientales contrastantes: San Antonio (SA, marino) y Mar Chiquita (MC, estuarial). Hembras maduras fueron recolectadas mensualmente por 1.5 años y el ciclo ovárico fue descrito usando una escala cualitativa. Los índices gonadosomático (GSI) y hepatosomático (HSI) fueron calculados. Los mayores valores de GSI y HSI tuvieron lugar al inicio de la estación reproductiva en SA, y durante la estación no reproductiva en $\mathrm{MC}$. El inicio y duración de la estación reproductiva también difirieron entre las poblaciones: ésta comenzó más tarde y fue más corta en SA. En MC, la vitelogénesis secundaria continuó cuando la estación reproductiva había finalizado, y el ovario permaneció desarrollado durante la estación no reproductiva (invierno). En consecuencia, las hembras de MC estaban listas para poner sus huevos tan pronto como aparecieron las condiciones ambientales de primavera. Por el contrario, las hembras de SA no alcanzaron un completo desarrollo del ovario durante el invierno. Un suministro limitado de alimento restringiría la energía disponible para completar la vitelogénesis secundaria al final de la estación reproductiva en SA, después de la última puesta. De ese modo, el ciclo vitelogénico debió completarse en la primavera siguiente, provocando un retraso en el comienzo de la estación reproductiva. Adicionalmente, la mayor amplitud térmica provocaría que la estación reproductiva finalice más temprano en SA.

Palabras clave: cangrejo, estuario, Argentina, ciclo ovárico, índice gonadosomático, índice hepatosomático. 


\section{INTRODUCTION}

Initial growth and development of crab oocytes is based on autochthonous material (primary vitellogenesis) but subsequent growth involves the contribution of allochthonous material (secondary vitellogenesis) (Nelson, 1991); at least in some species, reserves stored in the hepatopancreas are mobilized to the ovary during secondary vitellogenesis (Pillay and Nair, 1973; Kyomo, 1988; see Li et al., 2006 for complete references). In several crabs, multiple broods may be produced during an intermolt period (Morgan et al., 1983), and females develop a new cohort of oocytes as soon as a clutch is extruded. Thus, ovigerous females of these crabs may have ovaries either in primary or secondary vitellogenesis. When hatching occurs, secondary vitellogenesis of the second cohort is nearly complete, so a new clutch may soon be extruded. Finally, the last cohort of oocytes of the current season may arrest their development at the end of primary vitellogenesis and a premolt process begins (Nelson, 1991).

Multiple broods during the same reproductive season imply that gametogenesis and vitellogenesis are cyclic phenomena in iteroparous species ("ovarian cycle"). It is possible to detect several ovarian cycles during the reproductive season in a population by observing successive peaks in the proportion of both females with ripe ovaries and ovigerous females (e.g. González-Gurriarán, 1985; Sudha and Anilkumar, 1996; Mantelatto and Fransozo, 1999). Each ovarian cycle may be described by taking into account the changes in size and colour during oocyte development (e.g. Simons and Jones, 1981; Abelló 1989; González-Gurriarán et al., 1993; Rodríguez et al., 1997; Yamaguchi, 2001a).

Duration and frequency of the ovarian cycles of crustacea may vary among populations of a species (Sastry, 1983). The variation appears to be more noticeable if the species has a wide distribution range and if the environmental conditions vary over this range. Among the environmental factors which affect the ovarian cycle and the reproductive season, the effect of temperature and photoperiod has been widely demonstrated, but the effect of other factors, such as salinity and food availability, has been less studied.

Chasmagnathus granulatus Dana, 1851 is a semiterrestrial burrowing crab endemic to the warm temperate coast of the southwestern Atlantic from Rio de Janeiro, Brazil $\left(22^{\circ} 54^{\prime} \mathrm{S}, 43^{\circ} 11^{\prime} \mathrm{W}\right)$ to San

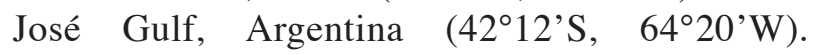

Populations of this crab are associated with mudflats and saltmarshes in estuaries, bays and coastal lagoons of varying salinities, temperatures and tidal patterns (Spivak, 1997). Its reproductive biology has been studied in different sites of its wide, but discontinuous, geographic distribution, and interpopulational differences in some life history traits have been observed (see Ituarte et al., 2004 and Bas et al., 2005 for complete references).

In particular, differences in embryonic and larval ecophysiology, and in life-history traits, were detected between two populations of $C$. granulatus that live under contrasting environmental conditions (temperature, rain regime, freshwater input, vegetation): Mar Chiquita lagoon, an oligo-polyhaline estuary, and San Antonio bay, an eu-hyperhaline habitat (Valero et al., 1997; Bas and Spivak, 2003; Bas et al., 2003, 2005). The purpose of the present study is to compare the ovarian cycles of these populations qualitatively and quantitatively in order to test if they differ in seasonality, duration and frequency.

\section{MATERIAL AND METHODS}

\section{Study areas}

San Antonio Bay (SA, Fig. 1A) is located in the northwest of San Matías Gulf, Río Negro Province, Argentina $\left(40^{\circ} 46^{\prime} \mathrm{S}, 64^{\circ} 50^{\prime} \mathrm{W}\right)$. This is a marsh without freshwater input, except for the scarce rains (200 mm/year). Moreover, excessive evaporation makes the water of San Matías Gulf hypersaline (Piola and Scasso 1988; Scasso and Piola 1988). The vegetation is composed predominately of Spartina alterniflora Loiseleur, 1807 (smooth cordgrass) and Sarcocornia perennis A.J. Scott, 1977 (Isacch et al., 2006) and the whole area is characterized by a dense population of $C$. granulatus (Bas et al., 2005). Mar Chiquita (MC, Fig. 1B) is a coastal lagoon located in Buenos Aires Province, Argentina (37 $32^{\prime}-37^{\circ} 45^{\prime} \mathrm{S}$ and $\left.57^{\circ} 19^{\prime}-57^{\circ} 26^{\prime} \mathrm{W}\right)$. A continuous supply of freshwater comes from several creeks and frequent rains $(800 \mathrm{~mm} /$ year). The water temperature and salinity show strong seasonal, daily and local variation, especially in the southern part of the lagoon which is more influenced by the sea (Anger et al., 1994). Intertidal environments in the lagoon comprise mud flats and large surrounding areas dominated by the "dense-flower cordgrass" Spartina densiflora Brongniart, 1829 (Isacch et al., 2006). 


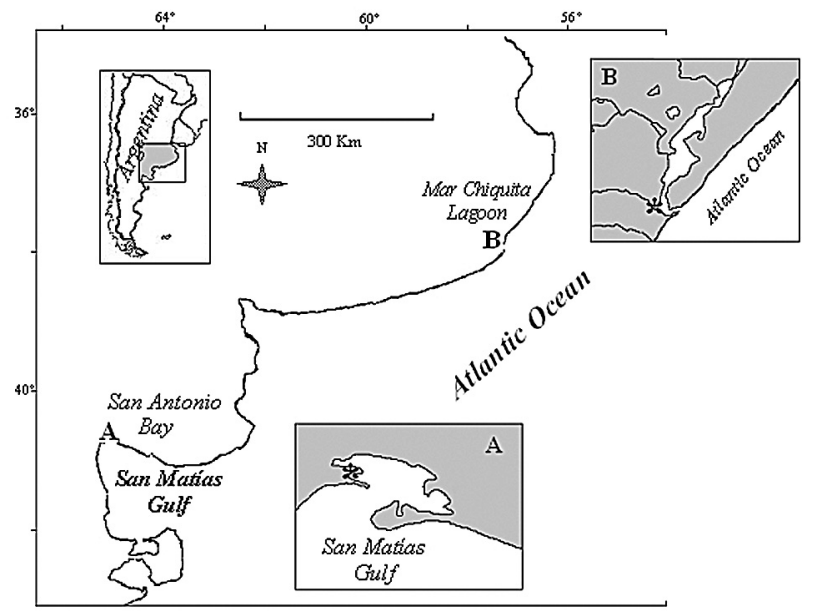

Fig. 1. - Study sites. A) San Antonio Bay and B) Mar Chiquita Lagoon.

\section{Environmental data}

Daily minimum and maximum air temperature of San Antonio Oeste and Mar del Plata airports (both meteorological stations were located no more than $20 \mathrm{~km}$ away from the study areas) were obtained from The National Climate Data Center, USA. Monthly mean air temperature was calculated for the study period and used for comparing the two sites. The daily photoperiod was calculated as the time (hours) between sunrise and sunset.

\section{Crab collection and processing}

From 30 to 50 mature females were collected monthly by hand in both localities, from July 2002 to February 2004 (except May, August 2003 and January 2004 in SA and August 2003 in MC). Additional samples previously collected in MC (1999-2001; Ituarte, 2002) were used to calculate gonadosomatic (GSI) and hepatosomatic (HSI) indexes. Females were transported live to the laboratory, frozen to death at $-20^{\circ} \mathrm{C}$ and dissected. The presence of eggs in the ovigerous chamber was registered, and the carapace width of all females was measured with a Vernier caliper to the nearest $0.01 \mathrm{~mm}$.

Based on their macroscopic appearance gonads were assigned to one of the following five stages: S1, post-spawning; S2, recovering; S3, developing; $\mathrm{S} 4$, ripe; S5, ready for ovulation (Ituarte et al., 2004). The percentage of females with ovaries in each stage was calculated. Histological sections were made to correlate the gonadal stages based on macroscopic criteria with oocyte development. For this purpose, a group of females collected in MC were anaesthetized with cold and their ovaries were immediately placed in Bouin's fixative for 24 hours, washed in water, dehydrated in ethanol and embedded in paraplast. Sections were stained with hematoxylin-eosin. The largest axis of 10 fresh oocytes per each macroscopic ovarian stage (3 replicas per stage) was measured with a stereomicroscope and the mean value was calculated.

Ovaries and hepatopancreas of females were carefully dissected, dried for $48 \mathrm{~h}$ at $80^{\circ} \mathrm{C}$, and weighed individually to $0.0001 \mathrm{~g}$. The exoskeleton and remaining organs were also dried for $48 \mathrm{~h}$ at $80^{\circ} \mathrm{C}$ and weighed individually to $0.01 \mathrm{~g}$. Eggs of ovigerous females were previously removed. The GSI and HSI were calculated as the ratio (\%) between the dry weight of the organ and the whole crab including the organs. Mean and standard deviations of GSI and HSI were calculated for each sample.

\section{Statistical methods}

Normality and homogeneity of variances were checked prior to performing parametric tests. When data did not meet these assumptions appropriate transformations were performed, depending on the case. One-way ANOVA was used even when data did not follow a normal distribution due to its robustness to non-normality (Underwood, 1997). Differences between treatments after a significant ANOVA were tested with the StudentNewman-Keuls (SNK) test. Differences in mean temperature, mean photoperiod and mean size of ovigerous females were compared in the two localities with the Student-t test. The same test was used to compare the GSI in each ovarian stage in the two populations. Mean size of oocytes was compared between stages by one-way ANOVA. The mean percentage of females with mature ovaries was compared with a two-way ANOVA considering population and season as factors. Monthly differences between HSI of ovigerous and non-ovigerous females with ovaries in S1, S2 and S3 were compared using the Student-t test [ovigerous females only had ovaries in S1-S3 (see results) and consequently non-ovigerous females with ovaries in the same stages were selected for comparison]. Since HSI did not differ significantly among females with S1-S3 ovaries (one-way ANOVA), data of each reproductive condition were pooled. 
A)
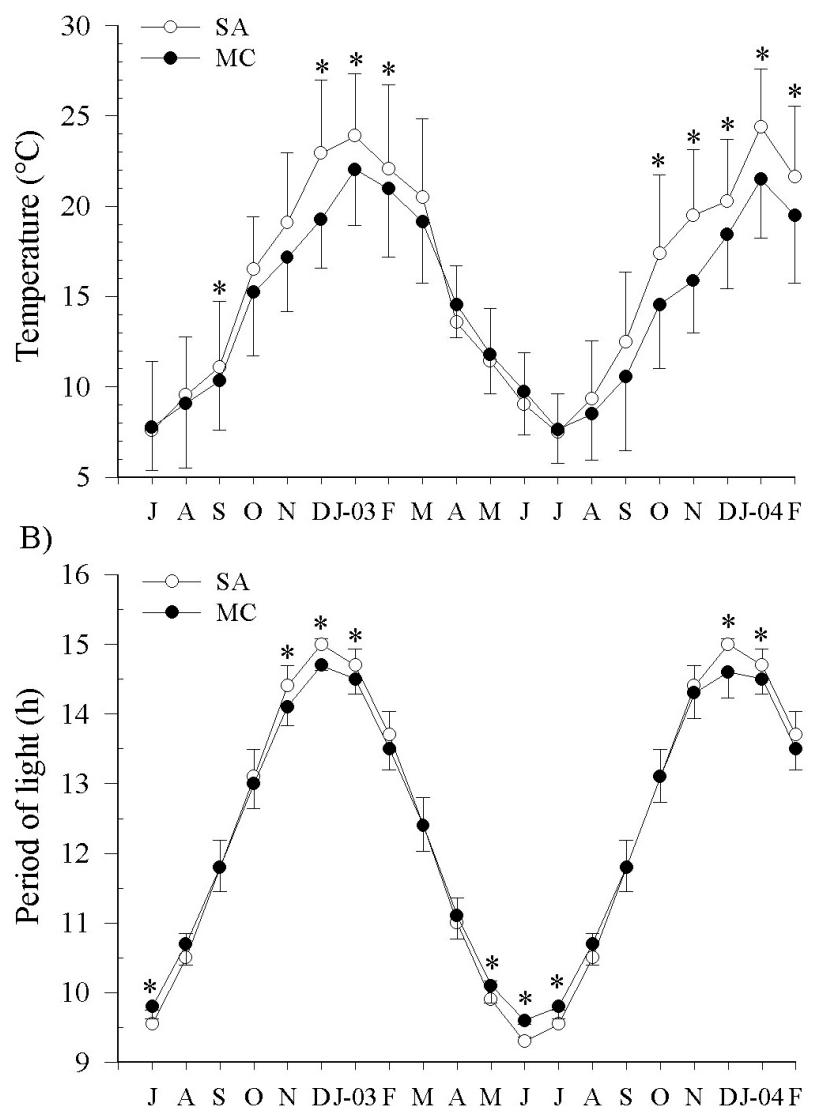

FIG. 2. - Monthly mean ( \pm 1 standard deviation) air temperature (A) and period of light (B) in San Antonio (SA) and Mar Chiquita $(\mathrm{MC})$; asterisks indicate significant differences between localities $(p<0.05)$

\section{RESULTS}

The annual pattern of monthly mean air temperature was similar in both sites. It increased from September to a maximum in January (SA: $24.0^{\circ} \mathrm{C}$, MC: $22.0^{\circ} \mathrm{C}$ ) and decreased from February to a minimum in July (both localities: $7.7^{\circ} \mathrm{C}$ ). It was significantly higher in SA than in MC from December 2002 to February 2003 and from October 2003 to February 2004 ( $p<0.05$; Fig. 2A). Extreme temperatures occurred in July 2003 and January 2003 respectively in both localities (SA: $-0.2^{\circ} \mathrm{C}$ and $32.4^{\circ} \mathrm{C}, \mathrm{MC}: 1.7^{\circ} \mathrm{C}$ and $30.2^{\circ} \mathrm{C}$ ). The period of light increased from a minimum in June to a maximum in December (SA: 9.3 - 15.0 h, MC 9.6 - 15.6 h, Fig. 2B). Periods with $<10 \mathrm{~h}$ light were observed in May, June and July in both localities, they were significantly longer in MC during these months. Periods with $>12 \mathrm{~h}$ light were observed from October to March, they were significantly longer in SA in December and January.

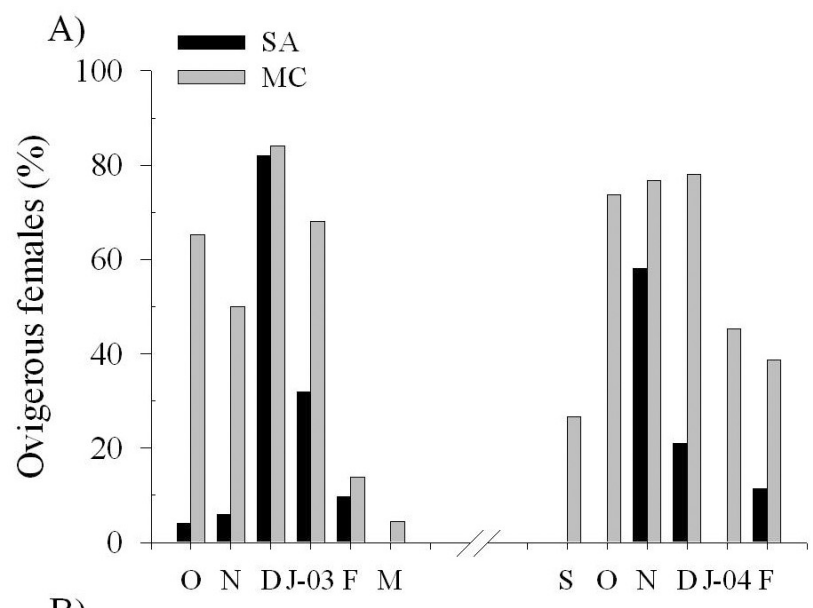

B)

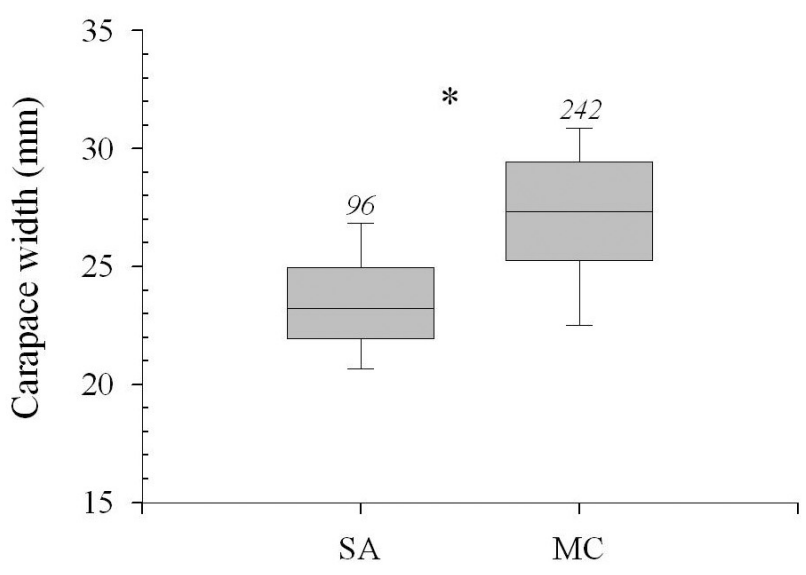

FIG. 3. - Chasmagnathus granulatus. Percentage (A) and mean size in $\mathrm{mm}$ (B) of ovigerous females in San Antonio (SA) and Mar Chiquita (MC). The number of females is indicated above each box; error bars show the 10th to 90th percentiles of the distribution; asterisk indicates significant differences between localities $(p<0.05)$.

The duration of the reproductive season, estimated by the presence of ovigerous females, differed between populations and consecutive years. In SA, ovigerous females were collected from October 2002 to February 2003, and from November 2003 to February 2004, with peaks in December 2002 and November 2003 (Fig. 3A). In MC, ovigerous females were present from October 2002 to March 2003 and from September 2003 to February 2004 with more than $50 \%$ occurring from October to February (Fig. 3A). Ovigerous females were significantly larger in $\mathrm{MC}(16.3-33.9 \mathrm{~mm} \mathrm{CW})$ than in SA (18.9 - $29.0 \mathrm{~mm} \mathrm{CW}$ ) (Fig. 3B).

In SA, GSI and HSI started to rise in August 2002, reached a peak simultaneously in November 2002, and fell to a minimum in December 2002 (Fig. 4). Nevertheless, while the GSI was $<1.0 \%$ from January to July 2003, the HSI increased from December to March, when it reached ca. $4.0 \%$, and 

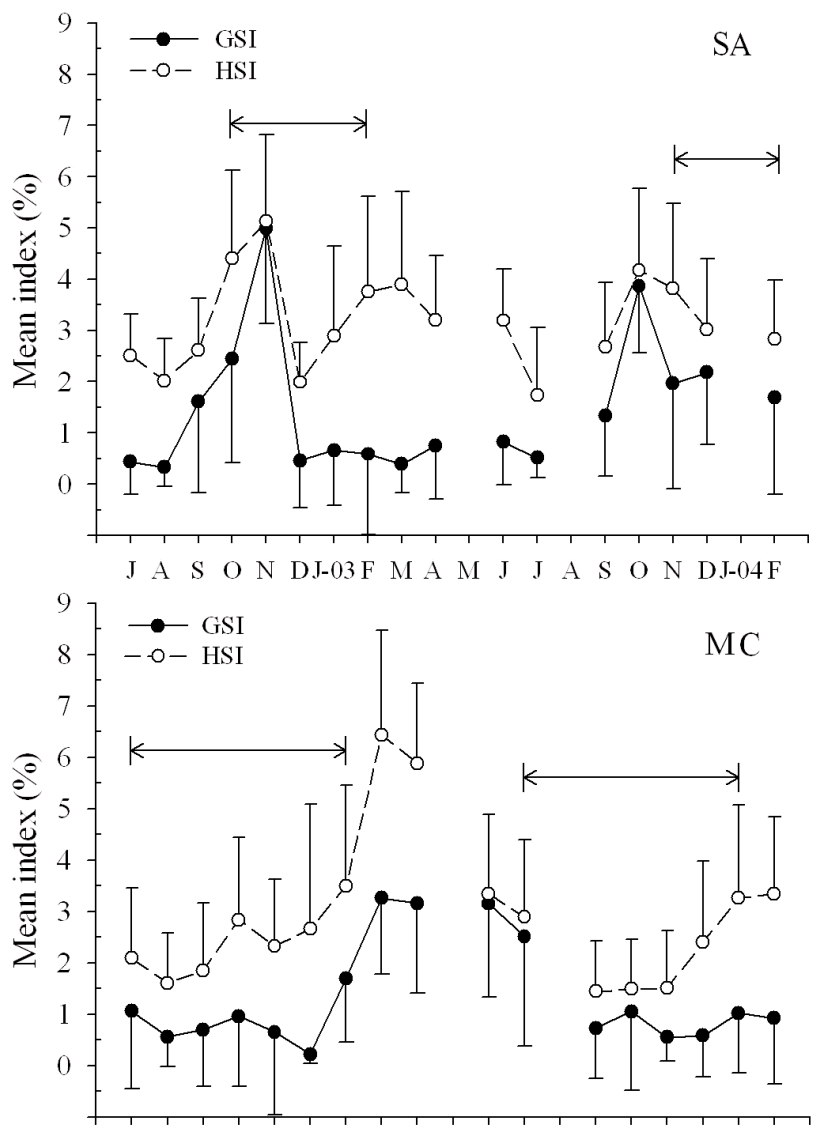

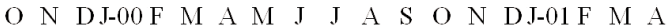

FIG. 4. - Chasmagnathus granulatus. Monthly mean ( \pm 1 standard deviation) gonadosomatic (GSI) and hepatosomatic (HSI) indexes in San Antonio (SA) and Mar Chiquita (MC) (the latter modified from Ituarte et al., 2004); horizontal arrows indicate the presence of ovigerous females.

then decreased to its lowest value in July 2003. Later, both indexes increased simultaneously from July to October 2003 and decreased in the following November (the HSI changed more gradually than the GSI). Maximum GSI occurred before the peak of ovigerous females (Fig. 3A) and simultaneously with the highest proportion of females with mature ovaries (see Fig. 5).

The highest GSI was observed in MC during the non-reproductive season (Fig. 4): it started to rise in March, reached its maximum in May and decreased in August and September, at the beginning of the following reproductive season. During this season, the GSI was $<1.0 \%$. The HSI was higher than the GSI during the entire year in MC and in SA, but in MC the HSI oscillated between 1.5-3.5\% during the reproductive season and a maximum $(6.5 \%)$ was registered in June (non-reproductive season).

Histological sections corresponding to the five macroscopic stages of the ovaries were in agreement

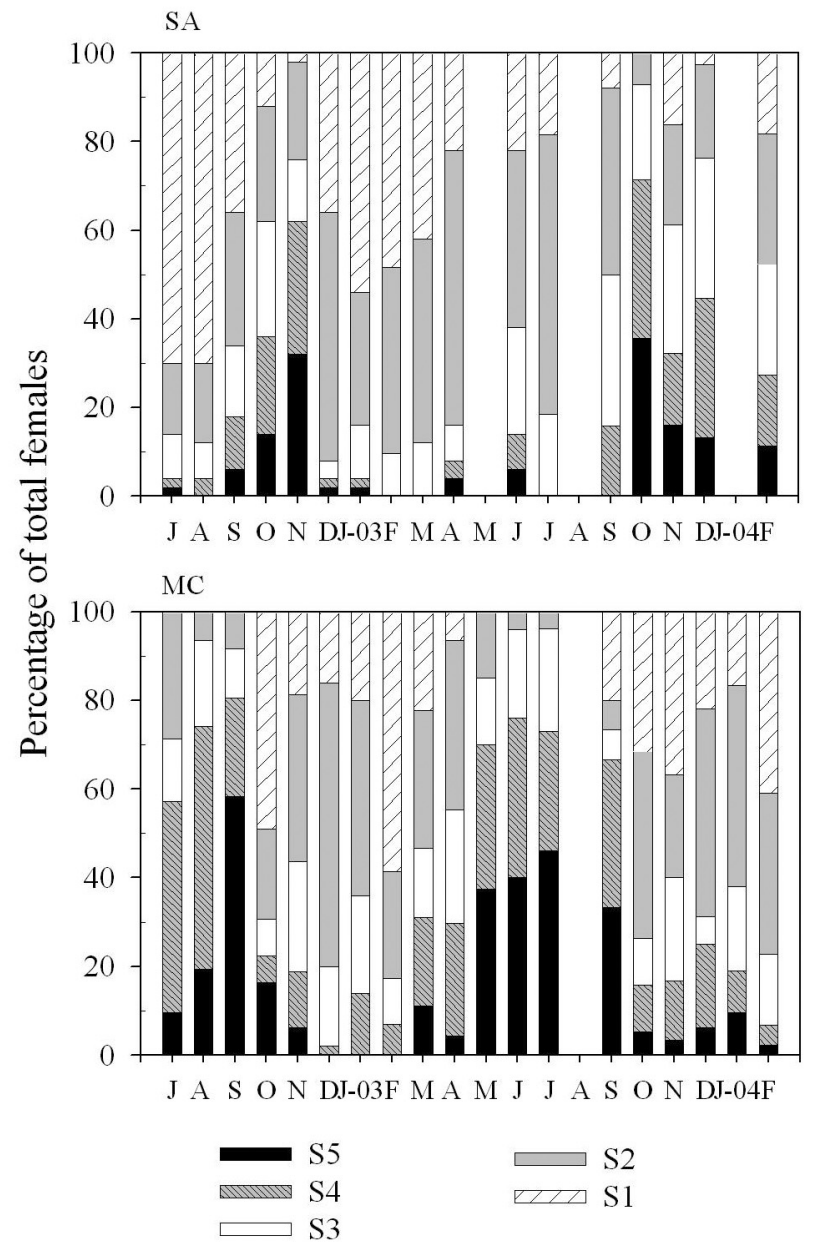

FIG. 5. - Chasmagnathus granulatus. Monthly percentage of ovarian stages among females collected in San Antonio (SA) and Mar Chiquita (MC). S1, post-spawning; S2, recovering; S3, developing; $\mathrm{S} 4$, ripe; $\mathrm{S} 5$, ready for ovulation.

with previous descriptions for this species (López Greco, 1997). Oogonies and primary oocytes prevailed in $\mathrm{S} 1$ and $\mathrm{S} 2$. The latter were larger than the oogonies, and had a homogeneous, clear basophile cytoplasm. In S2 (light-orange macroscopically) few secondary oocytes, which were recognized by being bigger with pink coloration, were observed. In $\mathrm{S} 3$, secondary oocytes predominated but a few primary oocytes were also observed. In S4 and S5, only secondary oocytes were observed, with a granular (S4) or grooved (S5) appearance. They increased their size and lost their circular shape in S5.

Size of fresh oocytes increased significantly throughout development in MC (Table 1; ANOVA: $\left.\mathrm{F}_{(3,106)}=136.9 ; p<0.0001\right)$. The increment was correlated with changes in the macroscopic appearance of the ovary. Oocytes were not detected under stereomicroscopy in S1 ovaries. The GSI increased throughout ovarian development and its relative 
TABLE 1. - Chasmagnathus granulatus. Oocyte size and ovarian stages (S2-S5) in MC; $n=30$ oocytes per stage, oocytes were not detected in S1. Different letters indicate significant differences (one-way ANOVA and SNK test; $p<0.0001$ ).

\begin{tabular}{lccc}
\hline Ovarian stages & \multicolumn{2}{c}{ Oocyte diameter $(\mathrm{mm})$} & Significance \\
& range & \\
\hline S2 & $0.132 \pm 0.018$ & $0.115-0.150$ & $\mathrm{a}$ \\
S3 & $0.207 \pm 0.005$ & $0.201-0.212$ & $\mathrm{~b}$ \\
S4 & $0.259 \pm 0.032$ & $0.227-0.291$ & $\mathrm{c}$ \\
S5 & $0.358 \pm 0.056$ & $0.313-0.403$ & $\mathrm{~d}$ \\
\hline
\end{tabular}

TABLE 2. - Chasmagnathus granulatus. Mean gonadosomatic index (GSI, the relative weight of the ovaries) \pm 1 standard deviation, and number of females with S1-S5 in San Antonio (SA) and Mar Chiquita (MC). P-value, with Student-t between populations with the same ovarian stage.

\begin{tabular}{lrrrrr}
\hline & \multicolumn{2}{c}{ SA } & \multicolumn{2}{c}{ MC } \\
Stage & mean \pm sd & N & mean \pm sd & N & p-value \\
\hline S1 & $0.22 \pm 0.15$ & 170 & $0.2 \pm 0.11$ & 266 & 0.16 \\
S2 & $0.52 \pm 0.43$ & 168 & $0.52 \pm 0.38$ & 197 & 0.89 \\
S3 & $1.69 \pm 0.95$ & 76 & $1.5 \pm 0.69$ & 143 & 0.12 \\
S4 & $3.4 \pm 1.21$ & 59 & $3.1 \pm 0.85$ & 77 & 0.12 \\
S5 & $5.11 \pm 1.34$ & 40 & $4.89 \pm 0.98$ & 76 & 0.38 \\
\hline
\end{tabular}

increment did not differ in the two populations (Table 2).

The pattern of ovary development differed between populations. Females with $\mathrm{S} 1$ and $\mathrm{S} 2$ ovaries predominated in SA during almost all the sampling period, except at the beginning of the reproductive season (Fig. 5, SA). The proportion of females with S4 and S5 ovaries (mature ovaries respectively ripe or ready to ovulate) increased from September to November 2002. The first ovigerous females appeared in October and most females were ovigerous (S1 and S2 ovaries) in December 2002, January and February 2003 (Fig. 5, SA). During the non-reproductive season, a high proportion of females had S1 to S3 ovaries (March to September $2003)$ and a low proportion $(<20 \%)$ had S4 and S5 ovaries in April, June and July. In October 2003,

TABLE 3. - Chasmagnathus granulatus. Summary of two-way analyses of variance of the proportion of mature ovaries in localities (SA and MC) and seasons (summer, winter, autumn and spring); dff: degrees of freedom of factors, MSf: mean squares of factors, dfe: degrees of freedom of errors, MSe: mean squares of errors, $F=$ MSf / MSe, $p$ : probability.

\begin{tabular}{lcccccc}
\hline Factor & dff & MSf & dfe & MSe & F & $p$ \\
\hline Season & 3 & 986 & 26 & 242 & 4.1 & $=0.017$ \\
Locality & 1 & 1450 & 26 & 242 & 17.12 & $<0.001$ \\
Season x Locality & 3 & 3870 & 26 & 242 & 15.9 & $<0.0001$ \\
\hline
\end{tabular}

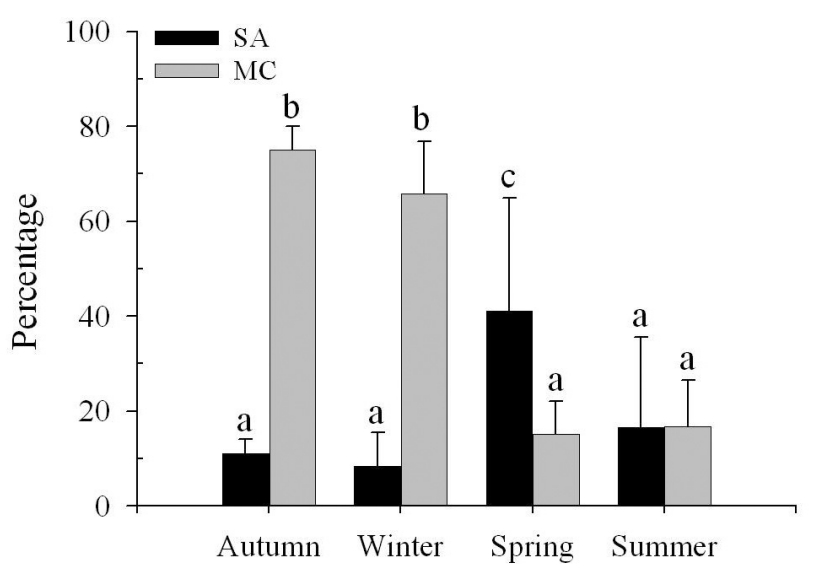

FIG. 6. - Chasmagnathus granulatus. Mean percentage (+ 1 standard deviation) of females with gonads in the two latter stages of development (S4-S5, mature ovaries) during April-June (autumn), July-September (winter), October-December (spring) and JanuaryMarch (summer) in San Antonio (SA) and Mar Chiquita (MC); different letters indicate significant differences.

$75 \%$ of females had mature ovaries again. The ovigerous females appeared in November 2003 and were present until February 2004. Throughout this period, $30-40 \%$ of females had mature ovaries. In

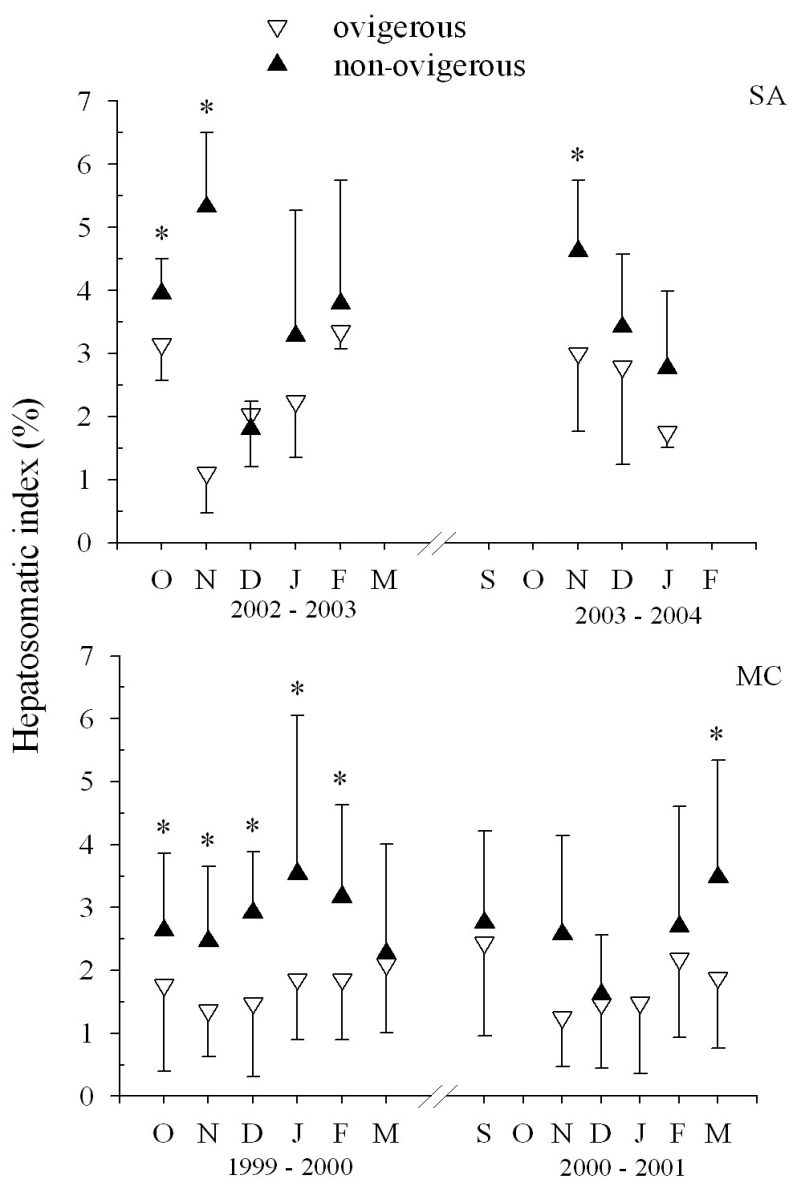

FIG. 7. - Chasmagnathus granulatus. Mean hepatosomatic index ( \pm 1 standard deviation) of non-ovigerous and ovigerous females in San Antonio (SA) and Mar Chiquita (MC); asterisks indicate significant differences between ovigerous and non-ovigerous females. 
MC, however, most females had S4 and S5 ovaries during the non-reproductive season: $55-80 \%$ from July to September 2002, and ca. $70 \%$ from May to September 2003 (Fig. 5, MC). More than 50\% of the females had S1 and S2 ovaries during both breeding seasons. In both localities, ovigerous females had only S1 to S3 ovaries (not shown).

The proportion of females with mature ovaries (S4 and S5 seasonally pooled) differed significantly between localities and seasons and the interaction between these factors was also significant (Table 3; Fig. 6). The most striking difference occurred in autumn and winter (non-reproductive season), when most MC females had S4 - S5 ovaries while less than $10 \%$ (on average) of SA females had developed ovaries (Fig. 6). The HSI was significantly higher in non-ovigerous than in ovigerous females in SA at the beginning of the reproductive season and in MC during the whole reproductive season 1999-2000 and at the end of the reproductive season 2000-2001 (Fig. 7).

\section{DISCUSSION}

Geographic variations in crustacean life history traits are well documented (Hines, 1989) and differences in reproduction and life history between latitudinally separated populations have been reported for several marine caridea, anomura and brachyura (Jones and Simons, 1983; Dugan et al., 1994, 1999; Lardies and Castilla, 2001; Lardies and Wehrtmann, 2001; Brante et al., 2004). For example, latitudinal gradients in temperature and photoperiod were correlated with changes in maximum size and size-atmaturity: larger sizes were observed at higher latitudes (Kinne, 1970; Jones and Simons, 1983; Lonsdale and Levinton, 1985). However, local physical and biological conditions (e.g. type of substratum, salinity, thermal physiology, competition, predation) may exert selective pressure and consequently produce variations in life history between crab populations (Simons and Jones, 1981; Jones and Simons, 1983).

Differences in reproduction and life history have been observed between two populations of Chasmagnathus granulatus: density is higher, crabs are smaller, eggs and larvae are larger and heavier, and the reproductive season is shorter in SA than in MC (Bas and Spivak, 2003; Bas et al., 2005; Bas et $a l$., unpublished data, this paper). Differences in the seasonality of ovarian development between these populations were also found in this study: during winter ovaries were mature in $\mathrm{MC}$, but remained in post-spawning or recovering stage in SA. In SA, the first ovarian cycle of the reproductive season is shorter, since it is completed during spring. In MC, however, secondary vitellogenesis lasted several months: it began in autumn (at the end of the previous reproductive season), probably continued in winter and finished at the start of the following spring. Variations in photoperiod, temperature, food, salinity and habitat structure (substrata) may act as environmental cues to adult physiological systems and to the offspring, thereby regulating gonad maturity and reproductive behaviour (Bauer, 1992). These environmental features may modify not only the physiology and behaviour of females, but also the quality, quantity and availability of food through indirect effects.

The effect of photoperiod on crab reproduction has been studied experimentally by comparing two rather different day lengths (e.g., Daniels et al., 1994). Subtle photoperiod differences exist between MC and SA and we assume that they do not affect reproductive seasonality. The indirect effects of photoperiod on cordgrass (Spartina spp) productivity have not been studied yet in these areas.

Temperature, which affects the cost associated with providing oxygen to the brood, explained the variation in some reproductive patterns observed in five brachyuran species along the Chilean coast (Brante et al., 2004). The temperature has also been mentioned as one of the causes (together with salinity and food quality) of the latitudinal changes in reproduction of Betaeus truncatus Dana, 1852 (Lardies and Wehrtmann, 2001) and Pinnaxodes chilensis Milne Edwards, 1837 (Lardies and Castilla, 2001). In the present study, mean temperatures were similar throughout most of the year in both sites, but higher in the southern location (SA) during spring and summer. However, ovigerous females appeared late in this population. Therefore, the mean temperatures did not have a direct correlation with the delay at the beginning of reproductive season in SA. However, in the temperate coast of Argentina, higher latitudes are correlated with an increase in temperature amplitude: minimum temperatures are comparatively lower and maximum temperatures higher in SA than in MC (Fig. 2A). $C$. granulatus, as an intertidal species, should be strongly influenced by thermal stress (Helmuth et $a l ., 2002)$. Cold "limits the active season, and hence 
time available for feeding, and therefore the energy available for growth and reproduction" of land crabs (Wolcott, 1988). The lower minimum air temperature that characterizes SA from February to August or September may contribute to the earlier end of the reproductive season compared with MC.

Differences in food quality or quantity in the two sites seem to be a major correlate of variation between populations. These factors explain variations in reproduction and life history traits of the intertidal crabs Macrophthalmus hirtipes Jaquinot, 1853; Grapsus albolineatus Lamarck, 1818 and Sesarma intermedia De Haan, 1835 (Simons and Jones, 1981; Kennish, 1996; Kyomo, 2000) and some terrestrial isopoda (Lardies et al., 2004; Hemmi and Jormalainen, 2004; Hassall et al., 2005). C. granulatus is a deposit-feeder but also an herbivorous crab, which sometimes feeds almost exclusively on cordgrasses (Spartina spp.). Moreover, it has been shown that its diet varies between microhabitats (Iribarne et al., 1997). Dominant cordgrass species differ between SA and MC. Food quality and productivity may vary between sites as a consequence of differences in temperature, salinity, substrate, nutrient supply, photoperiod and also the chemical composition of the cordgrass species. Plant palatability may also be different, as in the USA Atlantic coast salt marshes (Pennings et al., 2001). No comparative studies of productivity or palatability between SA and MC saltmarshes are available. However, the organic matter content of sediments is higher in MC (Bas et al., 2005), which is a more productive area due to its estuarine condition (Carreto et al., 1974; Marcovecchio et al., 2005).

The hepatosomatic index has been used to make inferences on the nutritional condition of fishes (e.g. Htun-Han, 1978; Bolger and Connolly, 1989; Lambert and Dutil, 1997) and crabs (e.g. Yamaguchi, 2001b). In C. granulatus, the HSI showed differences between populations not only in the maximum values (the HSI was higher in MC, suggesting a more intense reserve accumulation) but also in seasonal changes (see below). However, the decrease in the HSI during the cold season in the two sites suggests that females used the accumulated reserves stored in the hepatopancreas to maintain themselves (Ituarte et al., 2004; this paper) because of the reduction in feeding activity of semiterrestrial crabs at low air temperatures (Wolcott, 1988) or due to a limited food supply.
Furthermore, seasonal changes in the HSI have been related to the reproductive activities in males of Uca lactea De Haan, 1835 (Yamaguchi, 2001b). Our results showed that the HSI also varied during the reproductive cycle of females: ovigerous females showed a lower HSI than non-ovigerous females (Fig. 7). Ovigerous females divide their energy among maintenance, oocyte development and maternal care (they beat pleon and pleopods oxygenating and cleaning the brood mass, Silva et $a l .$, 2004). All these processes are simultaneous and demand a large amount of energy; the reserves stored in the hepatopancreas supply this energy, since feeding diminishes in ovigerous females (Fernández et al., 2000).

The seasonal pattern of the GSI, as well as the HSI-GSI relationship, also differed between populations (Fig. 4). In SA, spring HSI and GSI peaks were sharp and coincident, reaching similar values during the shorter reproductive season. Apparently, reserves were accumulated at the beginning of spring in the hepatopancreas, which allowed simultaneous ovarian development; then, the hepatosomatic reserves were consumed by the ovigerous females. Reserves were accumulated again in the hepatopancreas during summer, and used for maintenance during the cold season when the ovaries remained undeveloped (at rest). In MC, the HSI and GSI reached a peak during autumn, but the maximum HSI was twice as high as the maximum GSI. In addition, while the HSI fell in winter, the GSI remained constant near its maximum value. Reserves were accumulated intensely during the beginning of autumn, and were then used not only for maintenance but also transferred gradually to the ovaries, which complete their development in winter. Ovaries of $C$. granulatus also remained developed during winter in the estuarine populations of Lagoa dos Patos and Samborombón Bay (Ruffino et al., 1994; López Greco and Rodríguez, 1999).

In summary, the pattern of ovarian development and the seasonality of reproduction varied between SA and MC populations of C. granulatus. Our results suggest that these variations could be related to the nutritional condition of females: the higher productivity in MC may cause ovaries to remain developed during winter; a restricted food supply in SA could limit ovary recovery after the last spawning of the reproductive season. The hypothesis that a better food supply would allow SA females to complete the secondary vitellogenesis and conse- 
quently to develop their ovaries during winter should be tested in future experiments under controlled conditions.

\section{ACKNOWLEDGEMENTS}

This study was funded by the Universidad Nacional de Mar del Plata (Grant $\mathrm{N}^{\circ}$ 227/03) and ANPCYT (Grant N 01-13527). We wish to thank A. Rossin for her help in histological sections; J. Alberti and P. Daleo for their field assistance and two anonymous referees for their suggestions and comments. RBI had a fellowship from CONICET.

\section{REFERENCES}

Abelló, P. - 1989. Reproduction and moulting in Liocarcinus depurator (Linneaus, 1758) (Brachyura: Portunidae) in the Northwestern Mediterranean sea. Sci. Mar., 53: 127-134.

Anger, K., E. Spivak, C. Bas, D. Ismael and T. Luppi. - 1994. Hatching rhythms and dispersion of decapod crustacean larvae in a brackish coastal lagoon in Argentina. Helgol. Meeresunt., 48: $445-466$

Bas, C. and E.D. Spivak. - 2003. Effects of embryonic salinity exposure on larval development in two populations of the estuarine crab Chasmagnathus granulatus Dana, 1851 (Crustacea: Brachyura). Invertebr. Reprod. Dev., 43: 117-123.

Bas, C., E. Spivak and K. Anger. - 2003. Diferencias intra e interpoblacionales en la tolerancia al ayuno y la capacidad de asimilación de reservas de la zoea I de Chasmagnathus granulatus (Decapoda, Grapsidae). V Jornadas Nacionales de Ciencias del Mar. Mar del Plata, Argentina.

Bas, C., T. Luppi and E. Spivak. - 2005. Population structure of the South American Estuarine crab, Chasmagnathus granulatus (Brachyura: Varunidae) near the southern limit of its geographical distribution: comparison with northern populations. Hidrobiologia, 537: 217-228

Bauer, R.T. - 1992. Testing generalizations about latitudinal variation in reproduction and recruitment patterns with sicyonid and caridean shrimp species. Invertebr. Reprod. Dev., 22(13): 193-202.

Bolger, T. and P.L. Conolly. - 1989. The selection of suitable indices for the measurement and analysis of fish condition. $J$. Fish Biol., 34: 171-182.

Brante, A. S. Cifuentes, H.O. Pörtner, W. Arntz, and M. Fernández. - 2004. Latitudinal comparisons of reproductive traits in five Brachyuran species along the Chilean coast. Rev. Chil. Hist. Nat., 77: 15-27.

Carreto, J.I., C.A. Verona, A.B. Casal and M.A. Laborde. - 1974 Fitoplancton, Pigmentos y Condiciones Ecológicas del Golfo San Matías. Campaña SAO. III, pp.49-76. Anales Comisión Investigaciones Científicas de la Provincia de Buenos Aires. Informe $\mathrm{N}^{\circ} 10$.

Daniels, W.H., L.R. D’Abramo and K.F. Graves. - 1994. Ovarian development of female red swamp crayfish (Procambarus clarkii) as influenced by temperature and photoperiod. J. Crust. Biol., 14: 530-537.

Dugan, J.E., D.M. Hubbard and A.M. Wenner. - 1994. Geographic variation in life history of the sand crab, Emerita analoga (Stimpson) on the California coast: Relationships to environmental variables. J. Exp. Mar. Biol. Ecol., 18: 255-278.

Dugan, J.E., A.M. Wenner and D.M. Hubbard. - 1999. Geographic variation in the reproductive biology of the sand crab Emerita analoga (Stimpson) on the California coast. J. Exp. Mar. Biol. Ecol., 150: 63-81.

Fernández, M., Ch. Bock, and H.O. Pörtner. - 2000. The cost of being a caring mother: the ignored factor in the reproduction of marine invertebrates. Ecol. Lett., 3: 1-8.

González-Gurriarán, E. - 1985. Reproducción de la nécora Macropipus puber (L.) (Decapoda, Brachyura), y ciclo reproductivo en la Ría de Arousa (Galicia, NW España). Bol. Inst. Español Oceanogr., 2: 10-32.

González-Gurriarán, E., L. Fernández, J. Freire, R. Muiño and J. Parapar. - 1993. Reproduction of the spider crab Maja squinado (Brachyura: Majidae) in the southern Galician coast (NW Spain). Shellfish Committee, ICES C.M. 1993/K:19,15 pp.

Hassall, M., A. Helden and T. Benton. - 2005. Phenotypic plasticity and interpopulation differences in life history traits of Armadillidium vulgare (Isopoda: Oniscidae). Oecologia, 137: 85-89.

Helmuth, B., C.D.G Harley, P.M. Halpin, M. O'Donnell, G.E. Hofman and C.A. Blanchette. - 2002. Climate change and latitudinal patterns of intertidal thermal stress. Science, 298: 1015-1017.

Hemmi, A. and V. Jormalainen. - 2004. Geographic covariation of chemical quality of the host alga Fucus vesiculosus with fitness of the herbivorous isopod Idotea baltica. Mar. Biol., 145: 759-768.

Hines, A. - 1989. Geographic variation in size at maturity in brachyuran crabs. Bull. Mar. Sci., 45: 356-368.

Htun-Han, M. - 1978. The reproductive biology of the dab Limanda limanda (L.) in the North Sea: gonosomatic index, hepatosomatic index and condition factor. J. Fish Biol., 13: 369-378.

Iribarne, O., A. Bortolus and F. Botto - 1997. Between-habitat differences in borrow characteristics and trophic modes in the southwestern Atlantic borrowing crab Chasmagnathus granulata. Mar. Ecol. Prog. Ser., 155: 137-145.

Isacch, J.P., C.S.B. Costa, L. Rodríguez-Gallego, D. Conde, M. Escapa, D.A. Gagliardini and O.O. Iribarne. - 2006. Distribution of saltmarsh plant communities associated with environmental factors along a latitudinal gradient on the southwest Atlantic coast. J. Biogeogr., 33(5): 888-902.

Ituarte, R.B. - 2002. Biología reproductiva de Chasmagnathus granulatus en la Laguna Mar Chiquita. Tesis de Grado. Universidad Nacional de Mar del Plata.

Ituarte, R.B., E. Spivak and T. Luppi. - 2004. Female reproductive cycle of the Southwestern Atlantic estuarine crab Chasmagnatus granulatus (Brachyura: Grapsoidea: Varunidae). Sci. Mar., 68: 127-137.

Jones, M. and M. Simons. - 1983. Latitudinal variation in reproductive characteristics of the mud crab, Helice crassa (Grapsidae). Bull. Mar. Sci., 33(3): 650-670.

Kinne, O. - 1970. Temperature: animals-invertebrate. In: O. Kinne (ed.), Marine Ecology, Vol 1, Environmental Factors, pp. 407514. Wiley-Interscience, London, England.

Kennish, R. - 1996. Diet composition influences the fitness of the herbivorous crab Grapsus albolineatus. Oecologia, 105: 22-29.

Kyomo, J. - 1988. Analysis of the relationship between gonads and hepatopancreas in males and females of the crab Sesarma intermedia, with reference to resource use and reproduction. Mar. Biol., 97: 87-93.

Kyomo, J. - 2000. Intraspecific variation of reproductive strategies of the crab Sesarma intermedia: a consequence of habitat variations. Bull. Mar. Sci., 66: 157-171.

Lambert, Y. and J-D. Dutil. - 1997. Condition and energy reserves of Atlantic cod (Gadus morhua) during the collapse of the northern Gulf of St. Lawrence stock. Can. J. Fish Aquat. Sci., 54: $2388-2400$

Lardies, M.A. and J.C. Castilla. - 2001. Latitudinal variation in the reproductive biology of the commensal crab Pinnaxodes chilensis (Decapoda: Pinnotheridae) along the Chilean coast. Mar. Biol., 139: 1125-1133.

Lardies, M.A. and I. Wehrtmann. - 2001. Latitudinal variation in the reproductive biology of Betaeus truncatus (Decapoda, Alpheidae) along the Chilean coast. Ophelia, 55: 55-68.

Lardies, M.A., M.J. Carter and F. Bozinovic. - 2004. Dietary effects on life history traits in a terrestrial isopod: the importance of evaluating maternal effects and trade-offs. Oecología, 138: $387-395$

Li, K., L. Chen, Z. Zhou, E. Li, X. Zhao and H. Guo. - 2006. The site of vitellogenin synthesis in Chinese mitten-handed crab Eriocheir sinensis. Comp. Biochem. Physiol., 143B: 453-458

Lonsdale, D.J. and J.S. Levinton. - 1985. Latitudinal differentiation in copepod growth: an adaptation to temperature. Ecology, 66: 
1397-1407.

López Greco, L.S. - 1997. Adquisición de la madurez sexual y caracterización del patrón de crecimiento y reproducción en Chasmagnathus granulata, Dana, 1851 (Brachyura, Grapsidae, Sesarminae) de Bahía Samborombón, Buenos Aires, Argentina. Ph.D. thesis, Univ. Buenos Aires, Argentina.

López Greco, L.S and E.M. Rodríguez. - 1999. Annual reproduction and growth of adult crabs Chasmagnathus granulata (Crustacea, Brachyura, Grapsidae). Cah. Biol. Mar., 40: 155-164.

Mantelatto, F.L.M. and A. Fransozo. - 1999. Reproductive biology and moulting cycle of the crab Callinectes ornatus (Decapoda, Portunidae) from the Ubatuba Region, SA Paulo, Brazil. Crustaceana, 72: 63-76.

Marcovecchio, J., H. Freije, S. De Marco, A. Gavio, L. Ferrer, S. Andrade, O. Beltrame and R. Asteasuain. 2005. - Seasonality of hydrographic variables in a coastal lagoon: Mar Chiquita, Argentina. Aquatic. Conserv.: Mar. Freshw. Ecosyst., 15(6): 180-191.

Morgan, S.G., J.W. Goy and J.D. Costlow, Jr. - 1983. Multiple ovipositions from single matings in the mud crab Rhithropanopeus harrisii. J. Crust. Biol., 3: 542-547.

Nelson, K. - 1991. Scheduling of reproduction in relation to moulting and growth in malacostracan crustaceans. In: A. Wenner and A. Kuris (eds.), Crustacean egg production, vol. 7, F. Schram (gen. ed.), Crustacean Issues, pp. 77-116. Rotterdam, A. A. Balkema.

Pennings, S.C., E.L. Siska and M.D. Bertness. - 2001. Latitudinal differences in plant palatability in Atlantic coast salt marshes. Ecology, 82: 1344-1359.

Pillay, K.K. and N.B. Nair. - 1973. Observations on the biochemical changes on gonads and other organs of Uca annulipes, Portunus pelagicus and Metapenaeus affinis (Crustacea) during the reproductive cycle. Mar. Biol., 18: 167-198.

Piola, A.R. and L.M. Scasso. - 1988. Circulación en el Golfo San Matías. Geoacta, 15: 33-51.

Rodríguez, A., P. Drake and A.M. Arias. - 1997. Reproductive periods and larval abundance patterns of the crabs Panopeus africanus and Uca tangeri in a shallow inlet (SW Spain). Mar. Ecol. Prog. Ser., 149: 133-142.

Ruffino M.L., M.D. Telles and F. D'Incao. - 1994. Reproductive aspects of Chasmagnathus granulata Dana, 1851 (Decapoda, Grapsidae) in the Patos lagoon estuary, Brazil. Nauplius, 2: 43-52.

Sastry, A.N. - 1983. Ecological aspects of reproduction. In: F.J.
Vernberg and V.B. Vernberg (eds.), Enviromental adaptations, vol. 8, D.E. Bliss (gen. ed.), The Biology of Crustacea, pp. 179270. Academic Press, New York.

Scasso, L.M. and A.R. Piola. - 1988. Intercambio neto de agua entre el mar y la atmósfera en el Golfo San Matías. Geoacta, 15: 13-31.

Silva, P., Luppi, T. and E. Spivak. - 2004. Epibiosis on embryos and brooding care in two estuarines crabs, Chasmagnathus granulatus and Cyrtograpsus angulatus (Brachyura: Varunidae). $3^{r d}$ Brazilian Crustacean Congress and The Crustacean Society Meeting. Florianópolis, Brazil.

Simons, M.J. and M.B. Jones. - 1981. Population and reproductive biology of the mud crab, Macrophthalmus hirtipes (Jacquinot, 1853) (Ocypodidae), from marine and estuarine habitats. J. Nat. Hist. 15: 981-994.

Spivak, E.D. - 1997. Cangrejos estuariales del Atlántico sudoccidental $\left(25^{\circ} 41^{\prime}\right.$ S) (Crustacea: Decapoda: Brachyura). Inv. Mar., Valparaiso, 25: 105-120.

Sudha, K. and G. Anilkumar. - 1996. Seasonal growth and reproduction in a highly fecund brachyuran crab, Metopograpsus messor (Forskal) (Grapsidae). Hydrobiologia, 319: 15-21.

Underwood, A. - 1997. Experiments in Ecology: their logical design and interpretation using analysis of variance. Cambridge University Press.

Valero, J., O. Iribarne and M. Narvarte. - 1997. Geographic variation in fecundity, reproductive investment and egg size in the estuarine crab Chasmagnathus granulata. Resumos expandidos, VII Congreso Latino-Americano sobre Ciencias do Mar, 2: 514-516.

Wolcott, T.G. - 1988. Ecology. In: W.W Burggren and B.R. McMahon (eds.), Biology of the land crabs, pp. 55-96. Cambridge University Press. Cambridge.

Yamaguchi, T. - 2001a. The breeding period of the fiddler crab, Uca lactea (Decapoda, Brachyura, Ocypodidae) in Japan. Crustaceana, 74: 285-293.

Yamaguchi, T. - 2001b. Seasonal change of the hepatopancreas index in the males of the fiddler crab, Uca lactea. Crustaceana, 74(7): $627-634$

Received June 29, 2005. Accepted May 19, 2006.

Scient. ed.: J.B. Company.

Published online November 15, 2006. 